\title{
降雨-地形関係の時間・空間変動特性を考慮した 山岳域における降雨分布特性の解析
}

\author{
FLUCTUATION PROPERTIES OF PRECIPITATION-TOPOGRAPHY \\ RELATIONSHIPS IN MOUNTAINOUS REGIONS
}

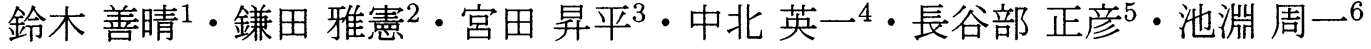 \\ Yoshiharu SUZUKI, Masanori KAMATA, Shohei MIYATA, Eiichi NAKAKITA, \\ Masahiko HASEBE and Shuichi IKEBUCHI \\ ${ }^{1}$ 正会員 工修 宇都宮大学助手 工学部建設学科建設工学講座 ( $7321-8585$ 宇都宮市陽東 7-1-2) \\ 2学生会員 宇都宮大学大学院 工学研究科エネルギー環境科学専攻 ( \\ 3 正会員 工修 (侏建設技術研究所 九州支社河川部 (广 810-0041 福岡市中央区大名 2-4-12) \\ ${ }^{4}$ 正会員 工博 京都大学大学院助教授 工学研究科都市環境工学専攻 (广 606-8501 京都市左京区吉田本町) \\ ${ }^{5}$ 正会員 工博 宇都宮大学教授 工学部建設学科建設工学講座 (T 321-8585 宇都宮市陽東 7-1-2) \\ ${ }^{6}$ フェロー工博 京都大学教授 防災研究所水資源研究センター (
}

\begin{abstract}
The purpose of this study is to clarify precipitation-topography relationships (PTRs) in mountainous regions on various spatiotemporal scales and to determine the physical mechanism of them. By running numerical simulations under realistic conditions using mesoscale model MM5, the PTRs in the Kinki region of Japan were investigated. PTRs on a spatial scale of a mountain slope were found to be described with a Gaussian-type function, which is referred to as GRIM (Gaussian-functional Relationship on an Isolated Mountain). And one of the conditions required for the formation of GRIM was determined: GRIM can be formed when regional average rainfall is more than 10 to $20 \mathrm{~mm}$ on a mountain slope. The spatiotemporal fluctuations of GRIM were, then, investigated to clarify how GRIM is connected with large-scale PTRs. As a result, large-scale PTRs were found to be formed by the summation of GRIM's. And it was clarified how large-scale PTRs vary according to the fluctuation properties of GRIM.
\end{abstract}

Key Words : precipitation-topography relationships, orographic precipitation, topographic elevation, mesoscale model, MM5

\section{1.はじめに}

近年, 数值計算の技術的進歩等により, メソスケー ルの降水現象に関する予測計算あるいは再現計算の精 度が飛躍的に高まっている．しかしながら，これらを 高精度で実行するためには，時空間的に密な気象観測 を行い, 詳細な初期・境界条件を得ることが不可欠で あるため, 今なおその適用可能地域はごく限られたも のとなっている.このような状況下においては, 例え ば山岳域における降雨-地形関係を明らかにすることで 普遍性の高い降雨分布特性を明らかにすることができ れば, それらの特性に基づいて様々な地域における降 雨分布推定が可能になるなど, 水文学的・工学的にそ の利用価值は非常に高いものになると考えられる.

本研究の対象である山岳域における降雨-地形関係, すなわち地形と積算雨量の空間分布が物理的・統計的に どのような関係にあるのかについては，世界各地にお いておよそ一世紀近くにわたって観測・解析が行われて きた $\left(\mathrm{Lee}^{1)}\right.$, Burns $^{2)}$, Daly et al. ${ }^{3)}$, Marquinez et al. $\left.{ }^{4}\right)$ など多数). それら多くの研究では, 地上雨量計による 観測に基づいて, 山岳域における地形標高と積算雨量
の関係がほぼ線形関係にあることや，様々な地形因子 が降雨の分布形状に影響を及ぼすことなどが報告され ている.しかしながら, $\mathrm{Mink}^{5)}$ やHevesi et al. ${ }^{6)}$ など 一部の研究では, 地形標高と積算雨量の関係は指数関 数等で表現され得る非線形的な関係にあるとの報告も あり，果たして地形標高と積算雨量の関係は真に線形 関係と言えるのか，また物理的にどのようなメカニズ ムでそのような関係が成立するのか，などについては これまで十分な議論がなされておらず，降雨-地形関係 に関する研究には今なお重要な課題が残されている.

一方，著者ら7),8) はこれまで，レーダーにより観測 された降雨データの解析や物理モデルを用いた数值シ ミュレーションによって，メソ $\beta$ スケール以上の時空 間スケールを持つ降雨分布を対象とした場合には,「降 雨分布の標高依存直線」と呼ばれる明確な降雨-地形関 係が成立することを明らかにした。これは, 地形標高 と積算雨量の層別平均值の間に片対数グラフ上で明確 な直線関係が成立するというもので, 領域平均的に見 た場合には, 地形標高と積算雨量の関係が指数関数的 な関係にあることを意味している。

さらに著者ら ${ }^{9)}$ は, 標高依存直線成立のメカニズム 

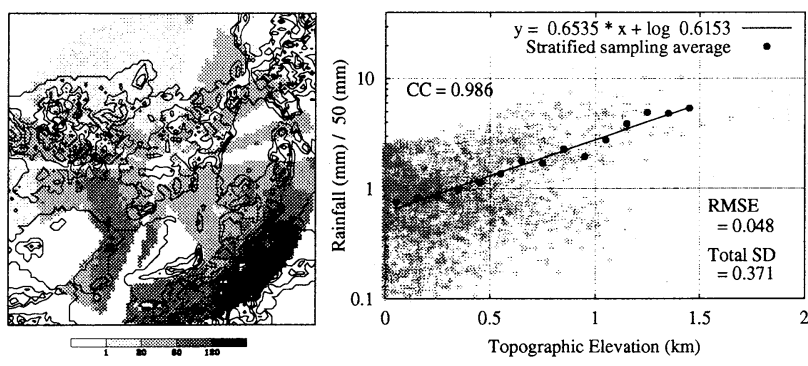

図-1 深山レーダ雨量計による観測值に基づいた地形標高と積 算降雨量の関係（積算期間: 88 年 8 月 10 日 0:00-23:40, 領域平均降雨量 : $50 \mathrm{~mm}$ )

解明を目指して，単峰性の山岳を地形条件として用い た実験的な数值シミュレーションを行ったところ，単 峰性山岳では降雨分布の標高依存直線が必ずしも成立 せず，その降雨-地形関係は「ガウス関数型の関数関係」 にあることが明らかとなった．また，その物理的なメ カニズムについて解析を行った結果，それは「積雲の 発達過程」がガウス関数的な変化を示すことに起因し ていると結論づけられた。しかしながら，実地形にお ける降雨分布の標高依存直線と, 単峰性山岳における ガウス関数型の降雨-地形関係がどのように結びつくの かについては十分な検討がなされておらず，現在のと ころ，その詳細なメカニズムは明らかでない。

そこで，本論文では，メソ気象モデル MM5 を用い た降雨の再現シミュレーションを行い, 山岳域におけ る降雨-地形関係およびそのメカニズムの解明を目的と して，様々な時間スケールおよび空間スケールを対象 とした降雨分布特性の解析を行う.

\section{2. 山岳域における降雨-地形関係}

\section{（1）降雨分布の標高依存直線}

近畿地方を観測刘象とする深山レーダ雨量計による 観測值をもとに, 観測領域内（半径 $120 \mathrm{~km}$ 円内）の各 地点 $(3 \mathrm{~km}$ グリッド) における地形標高と積算降雨量 との関係の一例を 図-1に示す．縦軸は，領域平均降雨 量で正規化した積算降雨量を表す対数軸である. 地点 雨量のばらつきは非常に大きいが，黒丸で示した積算 降雨量の層別平均値に着目すると, 相関係数 0.9 以上の 明確な直線関係が成立していることが分かる。この直 線関係を, 著者らは「降雨分布の標高依存直線」また は「降雨-地形関係の対数則」と呼んでいる. 同直線の 傾きの大きさや同直線周りの分散構造には, 対象地域 の地形特性や対象とする降雨イベントの性質がよく反 映されており, 同直線はある領域内の平均的な降雨-地 形関係を表す普遍性の高い降雨分布特性である.

これまで, 複数の地上降雨レーダーおよび人工衛星 登載レーダーTRMM/PR による観測や, 物理モデル を用いた降雨の再現シミュレーションにおいてその成 立が確認されている。 また, その成立条件の一つとし て, 数 $100 \mathrm{~km}$ 四方程度の領域を対象とした場合に, 領 域平均の降雨量が 50〜 100 mm 程度以上であることが 必要とされている7),8).
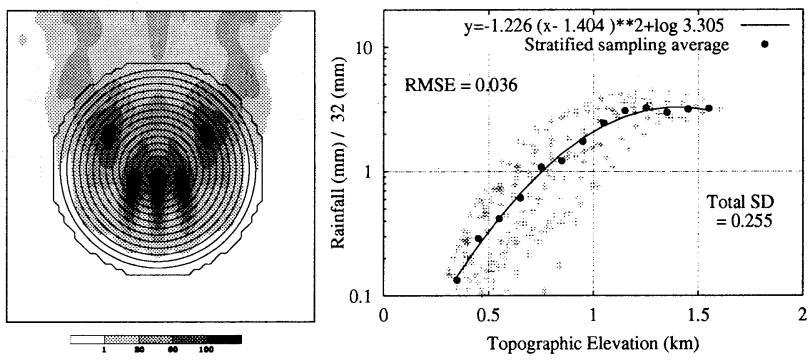

図-2 MM5 を用いた実験的シミュレーションによる 6 時間 積算降雨の分布（左図）と風上斜面における地形標高 と積算降雨量の関係（右図）（左図の下側が風上） 9 )
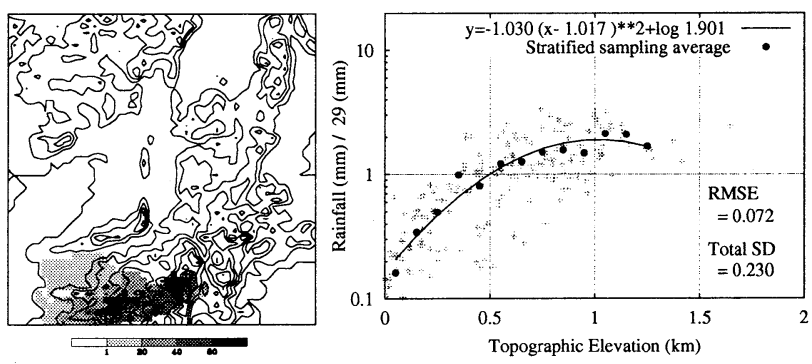

図-3 深山レーダ雨量計による観測值に基づいた一山岳斜面 における地形標高と積算降雨量の関係（紀伊山地西側 斜面, 積算期間 : 89 年 6 月 24 日 4:00-18:00)

\section{(2) ガウス関数型の降雨-地形関係}

鈴木ら ${ }^{9)}$ の行った MM5 を用いた実験的な数值シミュ レーションの結果より, 単峰性山岳における「ガウス 関数型の降雨-地形関係」を表したグラフの一例を 図-2 に示す. 円錐型山岳の山頂を境として風上斜面と風下 斜面を区別した上で，風上斜面における地形標高と 6 時間積算降雨量の関係を表したものである，同図中に 示した曲線は，積算降雨量の層別平均値を地形標高の 二次式で回帰したもので, 層別平均值が二次関数でよ く近似される様子が見て取れる．風下斜面（図は割愛） においては, 層別平均值がいくらか波状に変動するも のの，およそ一次の囘帰曲線に沿ったカーブを描く結 果となった。 すなわち, 単峰性山岳においては, 積算 降雨量の層別平均値 $r$ の対数値と, 地形標高 $z$ の関係 は次式のような二次関数で表すことができる.

$$
\begin{aligned}
& \log \frac{r_{k}}{R}=-a\left(z_{k}-b\right)^{2}+c \\
& \Longleftrightarrow \frac{r_{k}}{R}=C \exp \left[-a^{\prime}\left(z_{k}-b\right)^{2}\right] .
\end{aligned}
$$

ここで, $a, b, c$ は定数とし, $R$ は領域平均降雨量, 添 え字の $k$ は各標高区分を表す．また， $a^{\prime}=\ln 10 \times a$, $c^{\prime}=\ln 10 \times c, C=\exp \left[c^{\prime}\right]$ である.このとき，二次 関数を簡単に変形して得られる式 $(2)$ は，ガウス関数 型の式形となっており, 単峰性山岳における降雨-地形 関係が「ガウス関数型の関数関係」にあることを示し ている. 本論文では, 式(1) または式 (2) で表され る曲線関係を, 便宜的に『降雨-地形関係の GRIM 曲 線 (Gaussian-functional Relationship on an Isolated Mountain)』と呼ぶこととする.

ここで, GRIM 曲線が現実の降雨-地形関係において も成立するのかどうかについて，深山レーダ雨量計の 観測値を用いて調査したところ, 山岳の風上斜面を切り 

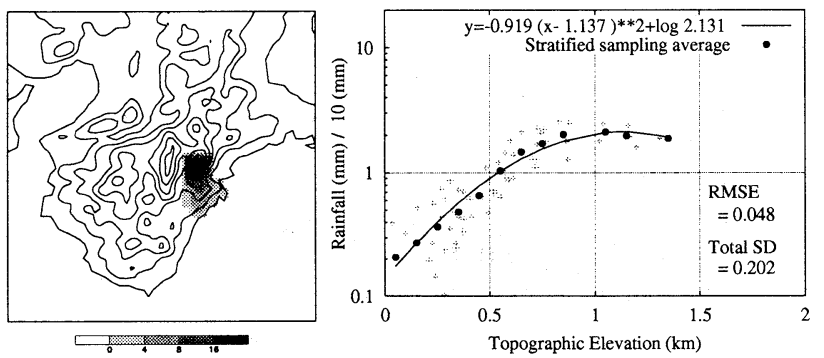

図-4 MM5 を用いた再現シミュレーションによる一山岳斜面 における地形標高と積算降雨量の関係（大台ヶ原山南 側斜面, 積算期間 : 99 年 9 月 14 日 12:50-14:30, 領域 平均降雨量 : $10 \mathrm{~mm}$ )

出すことによって, 確かに GRIM 曲線が成立している と判断される複数の事例の存在が確認された. 図-3に その一例を示す. 鈴木ら ${ }^{9)}$ によれば，このような特徴 的な降雨-地形関係が成立するのは,「積雲の発達過程」 がガウス関数的な変化を示すことに起因しているとい う解析結果が得られているが，このことからも特に山 岳の風上斜面において成立する非常に普遍性の高い降 雨分布特性ではないかと考えられる。

\section{3. 一山岳斜面における降雨-地形関係}

本節および次節では，鈴木ら ${ }^{8)}$ と同様に MM5 を用 いた日本の山岳域における再現シミュレーションを行 い, その計算結果を用いて降雨-地形関係の解析を行う. 計算条件は鈴木らと全く同様に設定し（詳細は文献に 譲る），各事例 48 時間の計算を行った。モデルによる 降雨分布の再現精度は，事例によっては必ずしも高い ものではないが，多雨域の位置など領域全体の傾向は 十分再現されていること，また，標高依存直線の傾きの 大きさについて，モデル雨量から求めた值とレーダー 観測雨量から求めた值が非常によい対応を示すという 結果が得られている8)ことなどから，本論文の目的に 対しては十分な精度を持つと判断した。

対象地域は「近畿南部 (紀伊山地)」とし，1998 年, 1999 年の 6 月〜 10 月に発生した降雨イベントの中から， 主に「地形をトリガーとして発生した対流性降雨が卓 越した事例」を対象に再現シミュレーションを行った。

\section{(1) 一山岳斜面における GRIM 曲線}

本論文では，ある一つの山岳斜面，すなわち適当な スケールで切り出された山岳の一斜面（例えば山岳の 東側斜面や南側斜面など）に着目して降雨-地形関係の 解析を行う。特に本論文では, 図-4 の左図に示したよ うに, 降雨-地形関係が比較的明確な紀伊山地大台ヶ原 山の南側斜面（尾熟市近辺を含む）に着目した．本節 および次節では，主に同斜面において解析を行う。

はじめに，同斜面における積算降雨量〉地形標高の 関係の一例を 図-4 の右図に示す. 図-3 と同様に, 一 山岳斜面において GRIM 曲線が成立する様子が見て取 れる.ここで, 他の事例や他の山岳斜面についても同 様に調査したところ, ある程度降雨の積分を行った場 合には，非常に多くのケースにおいて GRIM 曲線が成

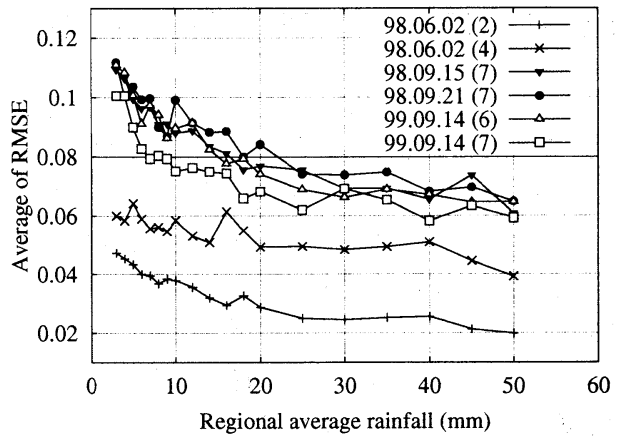

図-5 GRIM 曲線と層別平均值との偏差の大きさを表す RMSE（GRIM 曲線の RMSE）のサンプル平均と領 域平均降雨量との関係（括弧内の数字は山岳斜面番号）

立することが分かった．中には層別平均值が直線的に なるケースや, 降雨-地形関係があまり明確でないケー スも見られたが，今回のように，単峰性山岳の風上斜 面に相当すると考えられる一山岳斜面を適切に切り出 した場合には，現実の降雨-地形関係においても一般的 に GRIM 曲線が成立すると考えられる.

\section{(2) GRIM 曲線の成立条件}

ここで，GRIM 曲線が成立するためには，どの程度 の降雨積分を行えばよいかについて解析を行った. 各事 例ごとに, (降雨の積算期間を変化させて) 対象領域内の 平均雨量がほぼ等しい值を持つ降雨分布サンプルを複 数作成した上で，それらに対して図-4 と同様に GRIM 曲線を求めた。 さらに GRIM 曲線の成立度合を評価す るため, GRIM 曲線と層別平均值との偏差の大きさを 表す RMSE（以下, GRIM 曲線の RMSE）のサンプル 平均と領域平均降雨量との関係について調査を行った. 結果を図-5 に示す. なお, 鈴木ら ${ }^{8)}$ は, 「RMSE < $0.1 」$ を標高依存直線成立の判断基準として用いている。

同図より，領域平均降雨量が $10 \sim 20 \mathrm{~mm}$ 程度以上で あれば, RMSEの值が $0.08 〜 0.1$ 以下の值を取ることが 分かる．層状性降雨が卓越した事例を含めて約 10 事例 について検討した結果, RMSEの值が 0.08 以下の時に は十分 GRIM 曲線が成立しており，また $0.08 〜 0.1$ の 值を取る場合でも，目視により，全体的な傾向は GRIM 曲線によってよく近似されていると判断された。 すな わち, GRIM 曲線は「領域平均降雨量が $10 \sim 20 \mathrm{~mm}$ 程 度以上」の場合に成立する特性であると考えられる。

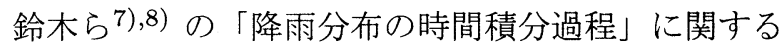
解析によれば, 数 $100 \mathrm{~km}$ 四方程度の領域を想定した場 合, 領域平均降雨量 $50 \sim 100 \mathrm{~mm}$ 程度以上において標 高依存直線が成立し，同 50〜100 mm 程度以下におい ては明確な降雨-地形関係を見ることはできないとされ ている. それに対して，上記の解析からは，数 $10 \mathrm{~km}$ 四方程度の一山岳斜面を対象とした場合には，およそ 領域平均降雨量 10〜20 mm 以上に才いて, GRIM 曲線 という明確な降雨-地形関係が成立することが明らかと なった。 山岳域の降雨-地形関係を明らかにするために は，このように異なった時空間スケールにおいて成立 する GRIM 曲線と標高依存直線がどのように結びつい ているのかを明らかにすることが必要である。 


\section{4. 降雨-地形関係の時間・空間変動特性}

鈴木ら ${ }^{9)}$ がすでに指摘しているように, 「山岳域の降 雨-地形関倸においてなぜ標高依存直線が成立するのか」 について考えたとき，その要因の一つとして「GRIM 曲線などの降雨-地形関係の重㸚合わせ」による影響が 考えられる. すなわち, 既に述べたように, 標高依存 直線は時間的・空間的に比較的大きなスケールで成立 する特性であるが，それは GRIM 曲線などの時間的・ 空間的に変動の激しいより小さなスケールにおける降 雨-地形関係が重㸚合わされることによって成立してい るのではないかと考えることができる.

そこで本節では, 98 年 9 月 21 日〜 22 日（以下, Case 1）および 99 年 9 月 14 日〜15 日（以下, Case 2) の 2 事例を対象として, 実際にモデル雨量より GRIM 曲線 等を求め, 降雨-地形関係の変動特性やその重站合わせ による影響について解析を行う。どちらの事例も, 台 風が近畿地方に接近したために比較的広い領域におい て非常に多くの地形性降雨が発生した事例である.

\section{(1) GRIM 曲線の重ね合わせ}

前節で得られた知見に基づいて, 領域平均降雨量が 約 $10 \mathrm{~mm}$ となるように時間を追って順に降雨を積算 し, 複数の降雨分布サンプルを作成した. また, 得られ た降雨分布 (Case 1 では 20 サンプル, Case 2 では 26 サンプル）に対してそれぞれ GRIM 曲線を求めた. 各 GRIM 曲線の RMSE の值を見ると，值が非常に大きく 明らかに GRIM 曲線が成立していないケースがいくつ か見られるものの, 半数以上 (Case 1 は $50 \%$, Case 2 は $65 \%$ \%) のサンプルで RMSE の值が 0.08 以下とな り, 明確な GRIM 曲線の成立が確認された。

次に，これら GRIM 曲線の「重ね合わせ」を行った。 結果を 図-6 および図-7 に示す. 複数の破線が各 GRIM 曲線を, 実線が全 GRIM 曲線を足し合わせて得られた 層別平均值 (黒丸) を回帰した結果を示している. ただ し, ここでの足し合わせは, 対数值ではなく害雨量の足 し合わせであることに注意されたい. 同図より，GRIM 曲線を足し合わせた結果が, やはり二次曲線により非 常に精度良く表現されることが分かる. さらに，各ケー スにおける全期間トータルの積算雨量分布より直接求 めた層別平均値 (白丸で示した, 従来の標高依存直線に 相当する）と黒丸とが非常によく一致しており，GRIM 曲線の重叔合わせにより, ある期間内（今回のケース では約 1 日）の平均的な降雨-地形関係が精度良く再現 されることが分かった。このことは，短い時間スケー ル (数洔間程度) の降雨-地形関係が GRIM 曲線によっ て十分表現されていることを意味している。

本論文では，このように GRIM 曲線の重ね合わせに より得られた二次の曲線関係を, 便宜的に『降雨分布 の標高依存曲線』と呼ぶこととする.

\section{（2） GRIM 曲線の時間変動特性}

ここで，図-6 および 図-7 において Case 1 と Case 2 の比較を行うと, 両者に特徵的な違いが見て取れる. Case 1 では, 片対数グラフ上において, 重㸚合わせ後

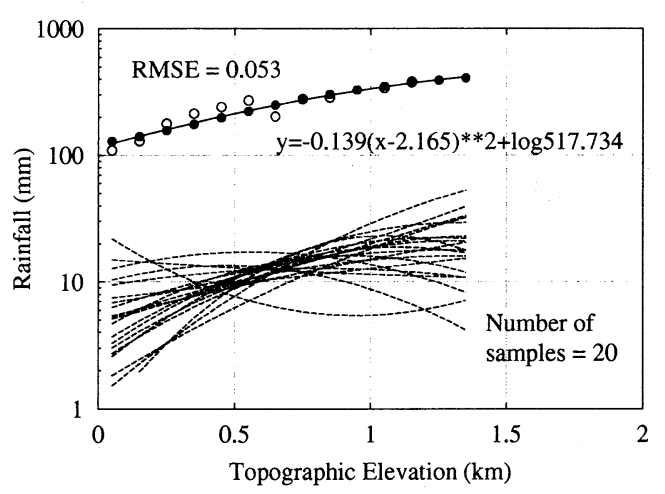

図-6 Case 1 における $10 \mathrm{~mm}$ 積算雨量分布に対して求めた GRIM 曲線（破線）とその重ね合わせにより得られた 標高依存曲線（黒丸および実線）

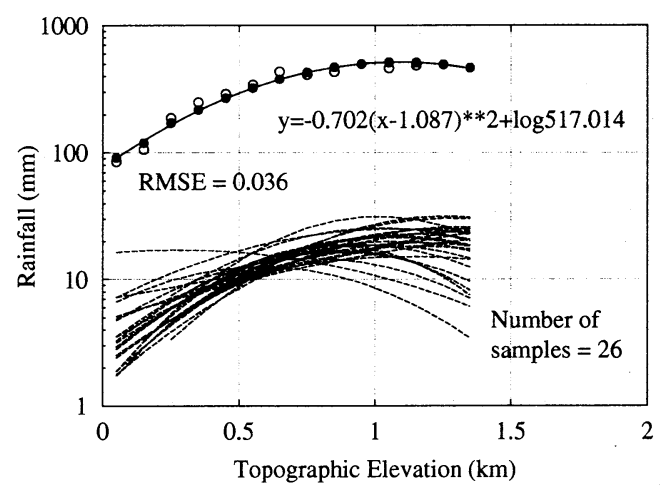

図-7 Case 2 における $10 \mathrm{~mm}$ 積算雨量分布に対して求めた GRIM 曲線（破線）とその重ね合わせにより得られた 標高依存曲線（黒丸および実線）

の標高依存曲線の曲率が小さく, 比較的直線的であるの に対して, Case 2 では非常に曲率が大きくなっている. このことは, GRIM 曲線の重㸚合わせにより表現され る降雨-地形関係が, その重㸚合わせの状況により, 直 線的にも曲線的にもなり得るということを示している. 実際, Case 1 と Case 2 における GRIM 曲線の重㸚合 わせの様子を比べてみると，両者が明らかに異なった様 子を示しており，Case 1 における GRIM 曲線の形状が 全体的により大きな変化を示していることが見て取れ る. すなわち, ある期間内の平均的な降雨-地形関係は, その間に GRIM 曲線がどのような変動を示すかに依存 して決まり，その変動が十分大きい場合には，降雨-地 形関係（標高依存曲線）が（片対数グラフ上で）より 直線的なものとなるのではないかと考えられる.

そこで, GRIM 曲線の時間的な変動特性を定量的に 評価するため, GRIM 曲線のパラメータ（式 (1) 参照) の時間変動について解析を行った，なお，以降の考察 では，特に断りが無い場合には片対数グラフ上におい て降雨-地形関係の形状や曲率等の議論を行う.

はじめに, パラメータ $a, b^{\prime}$ の值を時系列的に並べた 図を図-8 および図-9 に示す，なお，雨量のピーク位 置を表すパラメータbについては, 山岳斜面内の最高 標高 $(1307 \mathrm{~m})$ で正規化した值 $b^{\prime}$ を用いた。両図から は, GRIM 曲線が時間とともに様々に変動する様子が 見て取れる. 図-8からは，いくつかのケースにおいて， パラメータ $a$ が負の值を示す (GRIM 曲線が下に凸と 


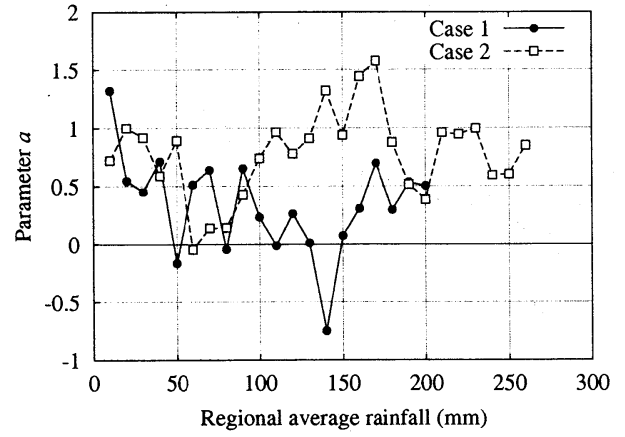

図-8 $10 \mathrm{~mm}$ 積算雨量分布に対して求めた GRIM 曲線のパ ラメータ $a$ の時系列変動（横軸は初期時刻から積算し た領域平均の降雨量を表す)

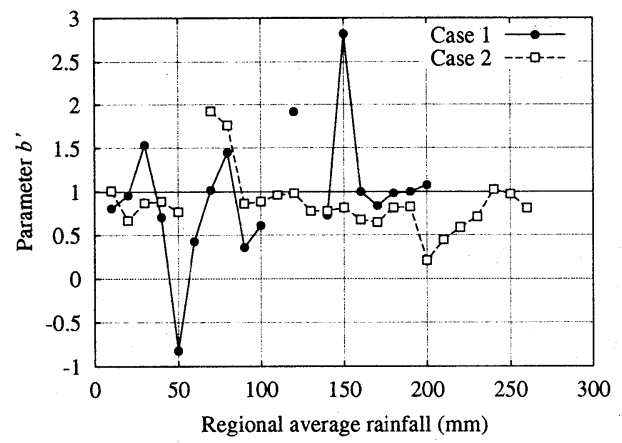

図-9 $10 \mathrm{~mm}$ 積算雨量分布に対して求めた GRIM 曲線のパ ラメータ $b^{\prime}$ の時系列変動（便宜的に $\left|b^{\prime}\right|>3$ となる絶 対值の大きなケースは除外した)

なる）ことや，絶対値が 0 に近い值を示す（GRIM 曲 線が直線的になる）ことが分かる．また，図-9 からは， Case 2 のピーク位置がほぼ山頂（最高標高点， $b^{\prime}=1$ ) 付近に位置するのに対して, Case 1 では大きな変動を 示していることが分かる.

ここで, 各パラメータの統計量を 表-1 に示す．ただ L, GRIM 曲線の直線性を議論するためには, パラメー 夕 $a$ のみでは必ずしも十分ではないため, GRIM 曲線 の「最大曲率」を計算し，その統計量を同表に示した. パラメータ $a$ および最大曲率の平均值を見ると, Case 1 の方がより小さな值を示しており，同ケースでは直線 的な GRIM 曲線の割合が高いことが分かる。一方，パ ラメータ $a$ および最大曲率の変動係数 (C.V.) につい て見ると, Case 1 においてより大きな值を示しており， GRIM 曲線が Case 2 よりも相対的により大きな変動を 示すことが分かる. GRIM 曲線の重ね合わせにより得 られた標高依存曲線のパラメータ $\left(a, b^{\prime}\right.$ に対応して $A$, $B^{\prime}$ とする）を見てみると, Case 1 においてパラメータ $A$ の值が小さく，また最大曲率も非常に小さな值を示 していることから, 確かに, GRIM 曲線の変動が大き いCase 1 においと，降雨-地形関係（噤高依存曲線）が 非常に直線的なものとなることが示された.

現在のところ, Case 1 と Case 2 の間で降雨-地形関 係がなぜこのような異なった特徵を示すのか，その詳 細なメカニズムは明らかでないが，両ケースの風速場 (図は割愛) を見ると，明らかにCase 1 における風向 の変動が大きく，鈴木ら ${ }^{9)}$ が指摘するように，風向や 風速の変動が重要な役割を果たしていると考えられる.
表-1 $10 \mathrm{~mm}$ 積算雨量分布に対して求めた GRIM 曲線およ びその重ね合わせによって得られた標高依存曲線のパ ラメータや最大曲率 (M-Curvature) の比較 ( $b^{\prime} に つ$ いては，便宜的に $\left|b^{\prime}\right|>3$ となる值を除外した）

\begin{tabular}{llll}
\hline \hline & & Case 1 & Case 2 \\
\hline \multirow{3}{*}{ Parameter $a$} & Average & 0.340 & 0.777 \\
& Variance & 0.174 & 0.138 \\
& C.V. & 1.226 & 0.479 \\
& Average & 0.966 & 0.866 \\
Parameter $b^{\prime}$ & Variance & 0.136 & 0.115 \\
& C.V. & 0.381 & 0.392 \\
& Average & 0.841 & 1.557 \\
M-Curvature & Variance & 0.416 & 0.543 \\
& C.V. & 0.767 & 0.473 \\
\hline Parameter $A$ & & 0.139 & 0.702 \\
Parameter $B^{\prime}$ & & 1.656 & 0.831 \\
M-Curvature & & 0.258 & 1.404 \\
\hline
\end{tabular}

\section{(3) 降雨-地形関係の空間変動特性}

上記の解析により, 時間的に大きな変動を示す GRIM 曲線を複数重ね合わせることによって, 標高依存曲線 がより直線的なものとなることが分かった．したがっ て, 積分期間を長く取り, 様々な GRIM 曲線を数多く 足し合わせることで, 標高依存曲線はさらに直線に近 づくと考えられる．すなわち，「標高依存直線」という 降雨-地形関係は，実際には「標高依存曲線」の収束形 として成立する特性ではないかと考えられる。しかし ながら，上記の解析では，降雨-地形関係の時間的重ね 合わせによって標高依存直線が成立することを示すま でには至っていない，そこで，以降の解析では領域を 拡大し，時間的重ね合わせに加えてさらに「空間的な 重ね合わせ」を行うことによって，標高依存曲線の形 状がどのように変化するか検討を行った。

はじめに，一つの山岳全体を含む一山岳領域におい て降雨-地形関係の調査を行った。その一例を 図-10に 示す. 右図に大台ヶ原山周辺領域における地形標高と積 算降雨量の関係, 左図にその対象領域を矢印で示した. 同図より，一山岳領域においても降雨-地形関係が二次 関数によってよく近似され，標高依存曲線が成立して いることが見て取れる. 風上斜面以外では, 必ずしも GRIM 曲線は明確には成立しないものの, 降雨-地形関 係のおよその傾向は十分表現されるため, 時間的重ね 合わせの場合と同様に, 複数の GRIM 曲線の空間的重 ね合わせにより標高依存曲線が成立すると考えられる.

次に, Case 1 および Case 2 を対象として, 図-10の 左図に示した山岳分割図に従って各山岳領域における 標高依存曲線を求め, それらの重ね合わせを行った．結 果を図-11 および 図-12 に示す。両図からは，標高依 存曲線 (破線) が, 山岳領域によって変動し, 様々な形 状を示すことが見て取れる，さらに，それらを足し合 わせた結果（黒丸）が，二次曲線により精度よく近似 されるとともに，全領域の積算雨量分布（山岳分割な し）から直接求めた層別平均值（白丸）をよく再現し ていることが分かる．両ケースを比較すると, Case 1 において，重ね合わせにより得られた標高依存曲線が 

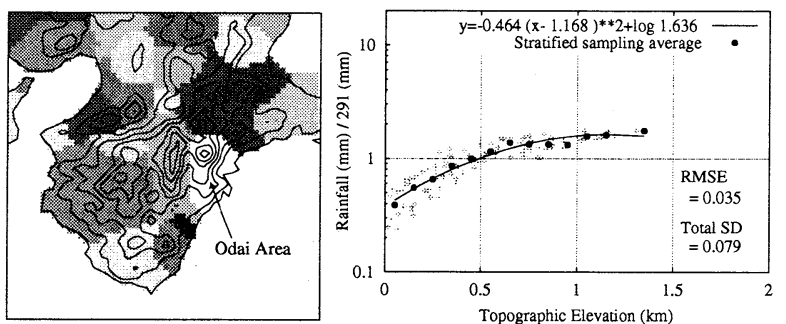

図-10 解析に用いた山岳分割 (左図) と一山岳領域における 地形標高と積算降雨量の関係（右図，大台ヶ原山周辺 領域, 積算期間 : 99 年 9 月 14 日 8:00 - 15 日 10:00)

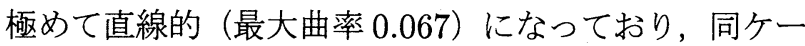
スでは「標高依存直線」が成立していることが確認さ れた. Case 2 においては, 重ね合わせ後の降雨-地形関 係がなおも曲線（最大曲率 0.862）を描いているが，こ れは, Case 2 における各標高依存曲線の曲率が全体的 に大きいことや，その変動が比較的小さいことなどが 影響していると考えられる.

以上より，降雨-地形関係の空間的重衫合わせによっ て必ずしも標高依存直線が成立するわけではないが，標 高依存直線は GRIM 曲線や標高依存曲線が時間的・空 間的に重㸚わされることによって成立するというそ の成立のメカニズムを明らかにすることができた.

\section{5. まとめ}

以上，本論文では，降雨-地形関係のメカニズム解明 を目指し，様々な時空間スケールで降雨-地形関係の解 析を行った結果, 以下の成果を得ることができた.

一山岳斜面程度の空間スケールに着目した場合には, 現実の降雨-地形関係においても，一般的にガウス関数 型の降雨-地形関係（GRIM 曲線）が成立することを示 すとともに, GRIM 曲線の成立条件の一つとして, 領 域平均降雨量 10〜20 $\mathrm{mm}$ 程度以上が必要であることを 明らかにした．さらに，ある期間内の平均的な降雨-地 形関係は，時間的に変動する複数の GRIM 曲線の重㸚 合わせによって表現され得ることを明らかにし，その 重ね合わせの結果が， GRIM 曲線と同様に，(片対数グ ラフ上で）二次関数によってよく近似されることを示 した（標高依存曲線の成立）。

また，GRIM 曲線の時間的・空間的な変動特性に関 す万解析を行った結果, 平均的な降雨-地形関係は, 重 ね合わせの対象となる GRIM 曲線がどのような変動を 示すかに依存して決まり，その変動が十分大きい場合に は, 降雨-地形関係（標高依存曲線）がより直線的なも のとなることが明らかとなった．このことから，「降雨 分布の標高依存直線」という降雨-地形関係は,「標高依 存曲線」の収束形として成立する特性であり,「GRIM 曲線や標高依存曲線の時間的・空間的な重㸚合わせ」に よって成立していることが分かった。

今後は，本論文で得られた知見の検証・精緻化を行う とともに，地形条件や気象条件を考慮した降雨-地形関 係の定式化や，降雨-地形関係をべースとしたグローバ ルな降雨分布推定モデルの構築に取り組む予定である.

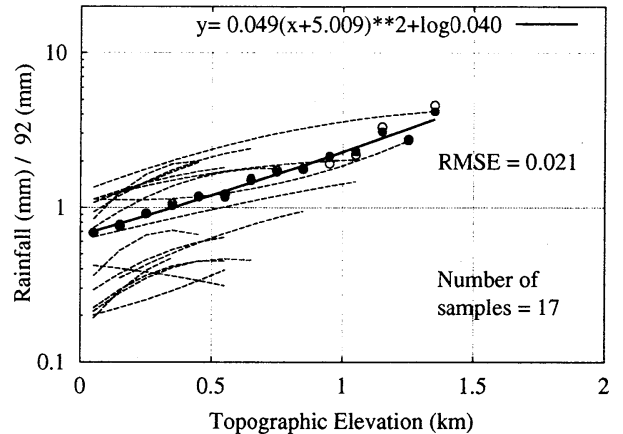

図-11 Case 1 における各山岳領域に対して求めた標高依存 曲線（破線）とその重ね合わせにより得られた標高依 存曲線（黒丸および実線）（積算期間 : 98 年 9 月 21 日 $7: 00-22$ 日 $8: 00)$

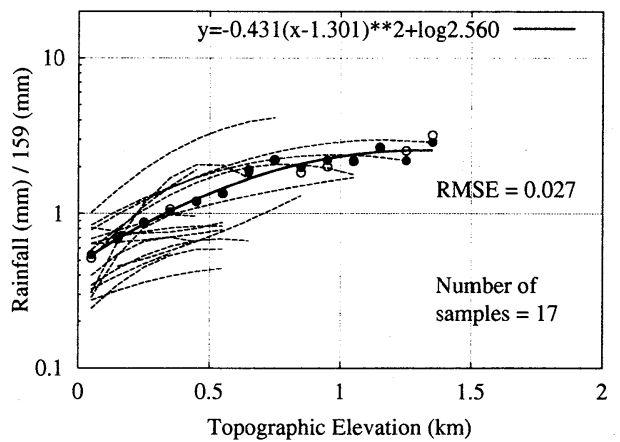

図-12 Case 2 における各山岳領域に対して求めた標高依存 曲線（破線）とその重ね合わせにより得られた標高依 存曲線（黒丸および実線）（積算期間 : 99 年 9 月 14 日 $8: 00-15$ 日 10:00)

\section{参考文献}

1) Lee, C. H.: Precipitation and altitude in the Sierra, Mon. Wea. Rev., Vol.39, pp.1092-1099, 1911.

2) Burns, J. I.: Small-scale topographic effects on precipitation distribution in San Dimas Experimental Forest, Trans. Am. Geophys. Union, Vol.34, pp.761-768, 1953.

3) Daly, C., Neilson, R. P. and Phillips, D. L.: A statistical-topographic model for mapping climatological precipitation over mountainous terrain, J. Appl. Meteor., Vol.33, pp.140-158, 1994.

4) Marquinez, J., Lastra, J. and Garcia, P.: Estimation models for precipitation in mountainous regions: the use of GIS and multivariate analysis, J. Hydrol., Vol.270(1-2), pp.1-11, 2003.

5) Mink J. F.: Distribution pattern of precipitation in the leeward Koolau Mountains, Oahu, Hawaii, J. Geophys. Res., Vol.65(9), pp.2869-2876, 1960.

6) Hevesi J. A., Istok J. D. and Flint A. L.: Precipitation estimation in mountainous terrain using multivariate geostatistics. Part I : Structural analysis, J. Appl. $\mathrm{Me}$ teor., Vol.31, pp.661-676, 1992.

7）鈴木善晴・中北英一・池淵周一: 標高依存直線に基づいた 降雨分布の地形依存特性の解明, 水工学論文集, 第 45 巻, pp.301-306 , 2001 .

8) 鈴木善晴・宮田昇平・中北英一・池淵周一 : メソ気象モデ ルによる数值シミュレーションに基づいた降雨-地形関係 の解析, 水工学論文集, 第 47 巻, pp.73-78, 2003.

9）鈴木善晴・宮田昇平・中北英一・池淵周一: 山岳域における 降雨-地形関係のメカニズムに関する数值実験的研究, 水 工学論文集, 第 48 巻, pp.289-294, 2004.

(2004.9. 30 受付) 